九州大学学術情報リポジトリ

Kyushu University Institutional Repository

\title{
Woodpeckers Appearance and Forest Vegetation Type in Urban Forests of Seoul Area, Korea
}

Hong, Suk-Hwan

Department of Landscape Architecture, Pusan National University

Kim, Ji-Suk

HUNECO, Urban ecology research center | HUNECO | Department of Landscape Architecture, Pusan National University

$\mathrm{Ki}$, Kyong-Seok

HUNECO, Urban ecology research center | HUNECO

Park, Seok-Gon

Depertment of Landscape Architecture, Sunchon University

他

https://doi.org/10.5109/27355

出版情報：九州大学大学院農学研究院紀要. 58 (2)，pp.253-258，2013-09. Faculty of Agriculture， Kyushu University

バージョン：

権利関係: 


\title{
Woodpeckers Appearance and Forest Vegetation Type in Urban Forests of Seoul Area, Korea
}

\author{
Suk-Hwan HONG ${ }^{1}$, Ji-Suk KIM ${ }^{1}$, Kyong-Seok KI ${ }^{2}$, Seok-Gon PARK ${ }^{3 *}$ \\ and Kiyoshi KUROSAWA
}

\author{
Institute of Tropical Agriculture, Kyushu University, Fukuoka 812-8581, Japan
}

(Received April 25, 2013 and accepted May 9, 2013)

\begin{abstract}
With the objective of protecting woodpeckers and forest environment, the relationship between the appearance of woodpeckers and the forest vegetation type was determined in urban forests of Seoul area. The target woodpecker species were the dominant woodpeckers in the area such as Japanese pygmy woodpecker (Dendrocopos kizuki), great spotted woodpecker (Dendrocopos major), and grey-faced green woodpecker (Picus canus). These species appeared mostly in the forest vegetation of Dahurian Birch (Betula davurica) and Japanese alder (Alnus japonica), which are grown in the valley in our study area. The appearance of woodpeckers is assumed to correlate with the woodpeckers' foraging activity for insects living in the soil. The soil moisture of the forest was thought to affect the inhabitation of insects. The population of grey-faced green woodpecker increased with an increase in the tree diameter at breast height $(\mathrm{DBH})$, while that of two other species increased only with small to medium tree DBH $(20-25 \mathrm{~cm})$. The reason for this is that the grey-faced green woodpecker grew larger than the other two species in biomass, needing relatively large trunks for their nesting unlike the other two species that had a relatively smaller biomass.
\end{abstract}

Key words: biomass, species, soil, diameter at breast height

\section{INTRODUCTION}

Bird habitat diversity and forest vegetation structure affect bird species diversity in forests (Lack, 1976; Cho, 1995; MacArthur and MacArthur, 1961). As a result of urbanization, resources are overused, vegetation structures are simplified, and the large trees are dwindling in the forests. In addition, the pollutant levels have soared. These factors obstruct the stable inhabitation of the forest birds (Kwak, 2011). In the past couple of decades, there is a decrease in plant species diversity and no increase in the tree DBH in the forests of Seoul City (Kwak, 2011). Therefore, the environment for bird habitat in Seoul area is gradually deteriorating.

The study of bird habitat in the forest can be divided into three categories: (1) genetics and morphological characteristics of birds, (2) diversity of bird species, and (3) factors affecting the characteristics and diversity of bird appearance (species and individual number). The last category focuses on the effects of vegetation structure (MacArthur and MacArthur, 1961; Austin, 1970; Moss, 1978) and tree diversity (Robinson and Holmes, 1982; Holmes and Schultz, 1986). Unlike the habitat of birds in natural forests, their habitat in urban forests is influenced by many factors including those man-made. Various studies have been conducted to investigate the relationship between the size of green spaces and the bird's appearance (Tilghman, 1987; Linehan et al., 1995;

\footnotetext{
1 Department of Landscape Architecture, Pusan National University, Miryang 627-706, Korea

2 HUNECO, Urban ecology research center, Seoul 138-050, Korea

3 Dept. of Landscape Architecture, Sunchon University, Suncheon 540-742, Korea

* Corresponding author (E-mail: sgpark@sunchon.ac.kr)
}

Gavareski, 1976; Galli et al., 1976). Wild birds present a unique appearance in urban forests, different from those in natural forests. However, only a few studies have been conducted to the best of our knowledge on the relationship between the ecological conditions of the urban forest and inhabitation of birds.

Since insects are the main source of food for woodpeckers, insect habitat and vegetation type, which influences the habitat of insects, could affect the appearance of woodpeckers. Water supports life at all biological stages (Goodwin et al., 2001). In urban forest, reduced solar radiation and moisture, coupled with a change of air temperature, affect not only the vegetation type but also the distribution of insects (Landsberg, 1981). Therefore, this study investigates the appearance of woodpecker species observed in urban forests in Seoul, Korea to determine its relationship with vegetation types. Our target species were the three dominant woodpecker species in Korea, that is, Japanese pygmy woodpecker (Dendrocopos kizuki; DK), great spotted woodpecker (Dendrocopos major; DM), and grey-faced green woodpecker (Picus canus; PC).

Woodpeckers are regarded as predators in the urban forest. Thus, this study could contribute toward protection of not only woodpeckers but also resources and environment of urban forests.

\section{MATERIALS AND METHODS}

\section{Study site}

Most of the forests in the Korean peninsula were destroyed during the Korean War (1950-1953). A largescale afforestation project was undertaken in the 1960s and 1970s by populating the bare mountains with trees from other countries. As a result of this afforestation 
drive, urban forests were divided into small pieces of either afforested or naturally regenerated areas by secondary succession. The topography of Korea is so diverse that some tree species do not grow in certain areas. Thus, the afforested areas resemble a mosaic of forests with different tree species.

A detailed actual vegetation map (on a scale of $1 / 1,000)$ was created for the first time for Seoul City. The map is most accurate actual vegetation map of Korea. Therefore, Seoul City is considered as the most appropriate area to study the relationships between the appearance of birds and vegetation type in a given area. The study site was identified to be the forests in and around the outskirts of Seoul City, including Namsan Urban Natural Park (center of Seoul) and Samleung and Dogok neighborhood parks (south area of Seoul), which represent the remaining forests in the area. The Cheonggyesan Urban Natural Park and Daemosan Urban Natural Park in the outskirts of Seoul City, and Godeok neighborhood park, Myeongil neighborhood park, and Iljasan neighborhood park (east area of Seoul) were also targeted. Developed areas (such as roads, housing, and sports facilities) within these sites were excluded from the study. The study sites are located at latitude $37^{\circ} 28^{\prime} 13^{\prime \prime} \mathrm{N}$ to $37^{\circ} 33^{\prime} 59^{\prime \prime} \mathrm{N}$ and longitude $126^{\circ} 58^{\prime} 35^{\prime \prime} \mathrm{E}$ to $127^{\circ} 10^{\prime} 13^{\prime \prime} \mathrm{E}$. The total area of the study site is $14.0 \mathrm{~km}^{2}$ (Figure 1).

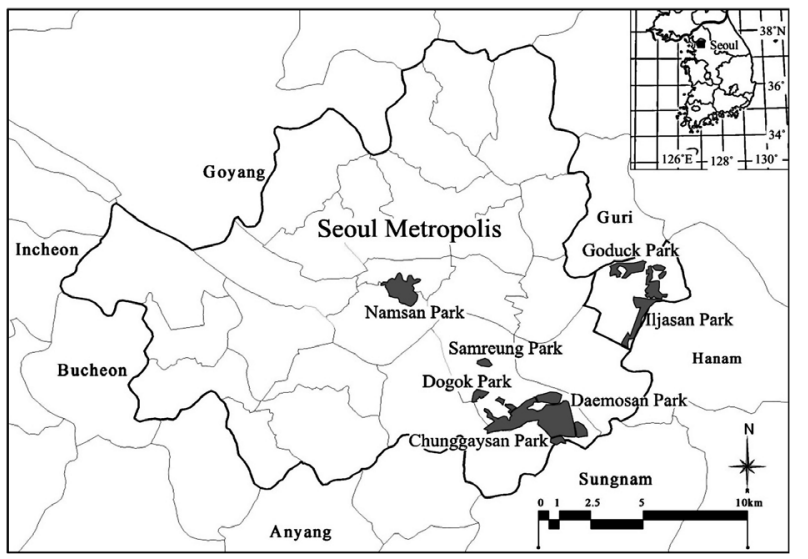

Fig. 1. Map of the surveyed area.

\section{Survey method}

The study area was surveyed by using the zig-zag method (Bibby et al., 2000) to determine the points to observe the appearance of woodpeckers. The points, where individual woodpeckers were found, were marked on the topographical map of Seoul (with a scale of $1 / 1,000)$ to record the exact locations. These location points were then digitized into spatial data using AutoCad software (Version 2012). A bird survey was conducted in 2001 and 2006 in the target area. Namsan Park was surveyed in winter (January) and in summer (August) of 2001. The forests in Gangdong-gu were surveyed in winter (January) and spring (April) of 2006, while the forests in Gangnam-gu were surveyed in winter (January) and in summer (August) of 2001.

\section{Actual vegetation}

To ascertain the actual vegetation of the forests, we used an actual vegetation map of Seoul on a scale of 1/1,000 published in 2000 and its updated version in 2004 and 2005 to enhance the reliability. For drawing the first actual vegetation map in 2000, a field survey was conducted by using a topographical map on a scale of $1 / 1,000$. Therefore, we used the same scale topographical map for surveying birds as well. Vegetation types of the forest and also the mean diameter of canopy trees at breast height (DBH) and vegetation coverage (\%) in each patch of vegetation type were parts of our survey. The geographical accuracy of this actual vegetation map was about 80\% (Cho et al., 2010). The ArcView 3.3 software was used for all geographical analysis for the spatial data.

\section{Data analysis}

To analyze the relationship between bird appearance, vegetation type, and tree DBH at each point of bird detection, we geographically overlaid the actual vegetation map with the bird detection points. Tree DBH was measured at $5 \mathrm{~cm}$ intervals. Land with a few trees, land in current use, and brushlands were not targeted. To confirm whether the appearance of woodpecker depends on tree sizes of each vegetation type, tree $\mathrm{DBH}$ for each actual vegetation type was analyzed.

As the frequency of woodpecker appearance at each actual vegetation type may be affected by the total area of each vegetation type, the bird appearance percentage for unit area was shown on a map. We used SPSS Software Ver. 17.0 for the statistical analysis.

\section{RESULTS AND DISCUSSION}

\section{Characteristics of vegetation distribution}

The study site is located adjacent to Seoul City. Following the damage of the land by the war, land used for purposes other than forests were scattered inside and outside the site. The afforested vegetation grown after the destruction caused by the war is distributed throughout the site. A total of 1,920 forest patches were targeted (Table 1). The average area of a patch was around $7,300 \mathrm{~m}^{2}$. There was a wide variety of 31 vegetation types in the study area, of which, 26 were dominated by woody plants including shrubs. Black locust (Robinia pseudoacacia) forest land, introduced from North America, occupied the largest area (approximately $14 \mathrm{~km}^{2}, 17.0 \%$ of total area). Farmland occupied the second largest portion $(16.2 \%)$ of our study area. Of the forest land, the indigenous Mongolian oak (Quercus mongolica) forest occupied $13.2 \%$ of the study area, followed by oriental chestnut oak (Q. acutissima) forest occupying $10.9 \%$ of the area. The exotic pich pine (Pinus rigida) forest covered $9.8 \%$ of the study area. Among the 31 vegetation types, 7 types had a small area, that is, less than 1 ha. The DBH of the forest trees dominated by woody plants excluding bushes was relatively small (a mean of 18.8 $\mathrm{cm}$ ), mainly because most of the forests were destroyed by the war and trees were harvested for fuel after the war until 1970s. 
Table 1. Area and occupying ratio of each vegetation type

\begin{tabular}{|c|c|c|c|c|c|}
\hline Vegetation type & $\begin{array}{c}\text { No. of } \\
\text { patches }\end{array}$ & Area $\left(\mathrm{m}^{2}\right)$ & Ratio (\%) & $\begin{array}{l}\text { Average area of } \\
\text { patch }\left(\mathrm{m}^{2}\right)\end{array}$ & $\begin{array}{l}\text { Average diameter at } \\
\text { breast height }(\mathrm{cm})\end{array}$ \\
\hline Ornamental planted area & 176 & 965,202 & 6.9 & 5,484 & - \\
\hline Grassland & 164 & 587,091 & 4.2 & 3,580 & - \\
\hline Bare ground & 49 & 88,591 & 0.6 & 1,808 & - \\
\hline Cultivated area & 185 & $2,270,278$ & 16.2 & 12,272 & - \\
\hline Woodcutting area & 5 & 6,118 & 0.0 & 1,224 & - \\
\hline Robinia pseudoacacia & 343 & $2,465,655$ & 17.6 & 7,188 & 20.1 \\
\hline Alnus sibirica & 51 & 168,172 & 1.2 & 3,297 & 19.3 \\
\hline Populus tomentiglandulosa & 81 & 389,224 & 2.8 & 4,805 & 21.4 \\
\hline Larix kaempferi & 19 & 104,613 & 0.7 & 5,506 & 19.9 \\
\hline Castanea crenata & 79 & 450,376 & 3.2 & 5,701 & 19.9 \\
\hline Pinus rigida & 194 & $1,373,005$ & 9.8 & 7,077 & 17.2 \\
\hline P. koraiensis & 65 & 235,762 & 1.7 & 3,627 & 9.5 \\
\hline P. densiflora & 95 & 512,891 & 3.7 & 5,399 & 14.9 \\
\hline Quercus mongolica & 133 & $1,843,964$ & 13.2 & 13,864 & 16.8 \\
\hline Q. aliena & 44 & 163,877 & 1.2 & 3,724 & 19.1 \\
\hline Q. serrata & 4 & 26,515 & 0.2 & 6,629 & 15.5 \\
\hline Q. variabilis & 1 & 8,815 & 0.1 & 8,815 & 18.0 \\
\hline Q. acutissima & 134 & $1,519,152$ & 10.9 & 11,337 & 18.2 \\
\hline Quercus spp. mixed & 17 & 205,302 & 1.5 & 12,077 & 16.6 \\
\hline Alnus japonica & 11 & 25,923 & 0.2 & 2,357 & 20.4 \\
\hline Betula davurica & 13 & 48,510 & 0.3 & 3,732 & 17.3 \\
\hline Prunus spp. & 15 & 188,386 & 1.3 & 12,559 & 23.2 \\
\hline Deciduous broad-leaved mixed & 11 & 66,036 & 0.5 & 6,003 & 17.4 \\
\hline Young Quercus spp. & 1 & 2,634 & 0.0 & 2,634 & 18.0 \\
\hline Ailanthus altissima & 1 & 362 & 0.0 & 362 & 12.0 \\
\hline Zelkova serrata & 2 & 6,340 & 0.0 & 3,170 & 47.5 \\
\hline Fraxinus rhynchophylla & 1 & 979 & 0.0 & 979 & 15.0 \\
\hline Sorbus alnifolia & 8 & 166,218 & 1.2 & 20,777 & 17.8 \\
\hline Shrubs & 16 & 71,646 & 0.5 & 4,478 & - \\
\hline Salix koreensis & 1 & 1,142 & 0.0 & 1,142 & 16.0 \\
\hline Rocky terrain & 1 & 19,873 & 0.1 & 19,873 & - \\
\hline Total & 1,920 & $13,982,652$ & 100.0 & 7,283 & Mean \\
\hline
\end{tabular}

\section{Woodpecker appearance by vegetation type}

The total number of individual woodpeckers appearing in the study site was 371, with DM being the largest (154 individuals), followed by DK (153 individuals) (Table 2). According to Won (1981), the dominant woodpecker species in the Korean forests is DM. In this study, however, DM and DK were almost the same in the number with each other, which might be due to that the target forest was an urban forest. Further survey is necessary on how the occupancies of DM and DK in urban forests are different from those in natural forests. We observed 64 individual birds of the PC, which had the largest biomass among the three species. We overlapped the actual vegetation type map with the appearance points, and counted the number of individuals appearing at each vegetation type. The result showed that the number of individuals appeared had a certain relationship with the vegetation type. All the three species of woodpeckers observed are solitary animals (Won, 1981); therefore, we were able to observe each woodpecker's secure territory. Woodpeckers were observed in 20 vegetation types, and not observed in the remaining 11 .

Since the woodpeckers move around freely, the general pattern of appearance by vegetation type in a small patch is difficult to determine. In this study, vegetation types, where no woodpeckers appeared, were in a small area. Therefore, we excluded the vegetation types in an area less than 1 ha and attempted to determine the woodpecker appearance characteristics for each species. There were seven vegetation types having an area with less than 1 ha, and no woodpeckers appeared in these areas. 
Table 2. Appearance of respective woodpeckers at each vegetation type

\begin{tabular}{|c|c|c|c|c|}
\hline \multirow{2}{*}{ Vegetation type } & \multicolumn{4}{|c|}{ No. of individuals } \\
\hline & Dendrocopos kizuki & Dendrocopos major & Picus canus & Sum \\
\hline Ornamental planted area & 2 & 11 & 5 & 18 \\
\hline Grassland & 1 & 3 & 1 & 5 \\
\hline Bare ground & 2 & 0 & 0 & 2 \\
\hline Cultivated area & 4 & 6 & 1 & 11 \\
\hline Woodcutting area & 0 & 0 & 0 & 0 \\
\hline Robinia pseudoacacia & 45 & 49 & 21 & 115 \\
\hline Alnus sibirica & 0 & 2 & 0 & 2 \\
\hline Populus tomentiglandulosa & 7 & 6 & 5 & 18 \\
\hline Larix kaempferi & 0 & 0 & 1 & 1 \\
\hline Castanea crenata & 12 & 16 & 4 & 32 \\
\hline Pinus rigida & 13 & 7 & 5 & 25 \\
\hline P. koraiensis & 1 & 1 & 0 & 2 \\
\hline P. densiflora & 2 & 2 & 0 & 4 \\
\hline Quercus mongolica & 19 & 14 & 6 & 39 \\
\hline Q. aliena & 1 & 5 & 1 & 7 \\
\hline Q. serrata & 0 & 0 & 0 & 0 \\
\hline Q. variabilis & 0 & 0 & 0 & 0 \\
\hline Q. acutissima & 31 & 24 & 11 & 66 \\
\hline Q. spp. Mixed & 0 & 0 & 0 & 0 \\
\hline Alnus japonica & 2 & 0 & 0 & 2 \\
\hline Betula davurica & 3 & 4 & 0 & 7 \\
\hline Prunus spp. & 0 & 3 & 0 & 3 \\
\hline Deciduous broad-leaved mixed & 0 & 0 & 0 & 0 \\
\hline Young Quercus spp. & 0 & 0 & 0 & 0 \\
\hline Ailanthus altissima & 0 & 0 & 0 & 0 \\
\hline Zelkova serrata & 0 & 0 & 0 & 0 \\
\hline Fraxinus rhynchophylla & 0 & 0 & 0 & 0 \\
\hline Sorbus alnifolia & 8 & 1 & 2 & 11 \\
\hline Shrubs & 0 & 0 & 1 & 1 \\
\hline Salix koreensis & 0 & 0 & 0 & 0 \\
\hline Rocky terrain & 0 & 0 & 0 & 0 \\
\hline Total & 153 & 154 & 64 & 371 \\
\hline
\end{tabular}

According to the analysis on the appearance percentage of each woodpecker for each vegetation type of unit area (Table 3), where all three species appeared, black birch (Betula davurica) forest had the highest appearance ratio (20.6\%), followed by Japanese alder (Alnus japonica), Japanese chestnut (Castanea crenata var. dulcis), and Korean mountain ash (Sorbus alnifolia) (Table 3). With respect to each species, DK had the highest appearance ratio in Japanese alder forest (23.2\%), followed by black birch, Korean mountain ash, and then Japanese chestnut forests. DM had the highest appearance ratio in black birch forest, followed by Japanese chestnut, Oriental white oak (Quercus aliena), and then black locust forests (Table 3). These two woodpecker species were distributed across several vegetation types at locations where they appeared most frequently. PC had the highest appearance ratio in bushes, followed by Suwon poplar (Populus tomentiglandulosa) and Korean mountain ash forests, which was different from our observations on the other two species (Table 3). This could be because of the difference in their main food. DK and DM usually eat insect larvae living inside tree trunks, and PC primarily eats ants (Won, 1981). However, the three targeted woodpecker species shared a common vegetation type (softwood deciduous forest), which grows in humid and low-lying valleys. Black birch and Japanese alder belong to the Betulaceae family and are representative of species grown in valleys in Korea. 
Table 3. Woodpecker's appearance ratio at each vegetation type (supposing each type is distributed over the same area)

\begin{tabular}{|c|c|c|c|c|}
\hline \multirow{2}{*}{ Vegetation type } & \multicolumn{4}{|c|}{ Appearance ratio (\%) } \\
\hline & Dendrocopos kizuki & Dendrocopos major & Picus canus & Sum \\
\hline Ornamental planted area & 0.6 & 4.2 & 5.5 & 2.7 \\
\hline Grassland & 0.5 & 1.9 & 1.8 & 1.2 \\
\hline Bare ground & 6.8 & - & - & 3.2 \\
\hline Cultivated area & 0.5 & 1.0 & 0.5 & 0.7 \\
\hline Robinia pseudoacacia & 5.5 & 7.3 & 9.1 & 6.7 \\
\hline Alnus sibirica & - & 4.3 & - & 1.7 \\
\hline Populus tomentiglandulosa & 5.4 & 5.6 & 13.8 & 6.6 \\
\hline Larix kaempferi & - & - & 10.2 & 1.4 \\
\hline Castanea crenata var. dulcis & 8.0 & 13.0 & 9.5 & 10.2 \\
\hline Pinus rigida & 2.8 & 1.9 & 3.9 & 2.6 \\
\hline P. koraiensis & 1.3 & 1.6 & - & 1.2 \\
\hline P. densiflora & 1.2 & 1.4 & - & 1.1 \\
\hline Quercus mongolica & 3.1 & 2.8 & 3.5 & 3.0 \\
\hline Q. aliena & 1.8 & 11.2 & 6.5 & 6.1 \\
\hline Q. serrata & - & - & - & - \\
\hline Q. acutissima & 6.1 & 5.7 & 7.8 & 6.2 \\
\hline Q. spp. mixed & - & - & - & - \\
\hline Alnus japonica & 23.3 & - & - & 11.0 \\
\hline Betula davurica & 18.6 & 30.2 & - & 20.6 \\
\hline Prunus spp. & - & 5.7 & - & 2.3 \\
\hline Deciduous broad-leaved mixed & - & - & - & - \\
\hline Sorbus alnifolia & 14.5 & 2.2 & 12.9 & 9.5 \\
\hline Shrubs & - & - & 15.0 & 2.0 \\
\hline Rocky terrain & - & - & - & - \\
\hline Total & 100 & 100 & 100 & 100 \\
\hline
\end{tabular}

\section{Relationship between average tree DBH and vege- tation type}

The average tree DBH in the study area was relatively small (approximately $20 \mathrm{~cm}$ ). We categorized the $\mathrm{DBH}$ of the dominant trees by $5 \mathrm{~cm}$ intervals, excluding areas that had few trees. The study area was categorized into six divisions from less than $10 \mathrm{~cm}$ to greater than $25 \mathrm{~cm}$ in tree $\mathrm{DBH}$, in order to assess the distribution according to unit area. The analysis revealed that the larger the tree DBH, the higher the number of individual woodpeckers around it. This trend was obvious for PC, which had the largest biomass among the species. DM and DK tended to have more individuals with the increase in DBH of the forest trees; however, their appearances decreased where the DBH was greater than $25 \mathrm{~cm}$ (Figure 2 ). Woodpeckers are the representative species to excavate holes in tree trunks for nesting; therefore, larger biomass species requires larger trees (Gunn and Hagan, 2000). The results of this study are similar to those of previous studies mentioned above.

This study focuses not on the features of nesting trees but on the location in the forest where the woodpeckers appear. We confirmed that the locations of

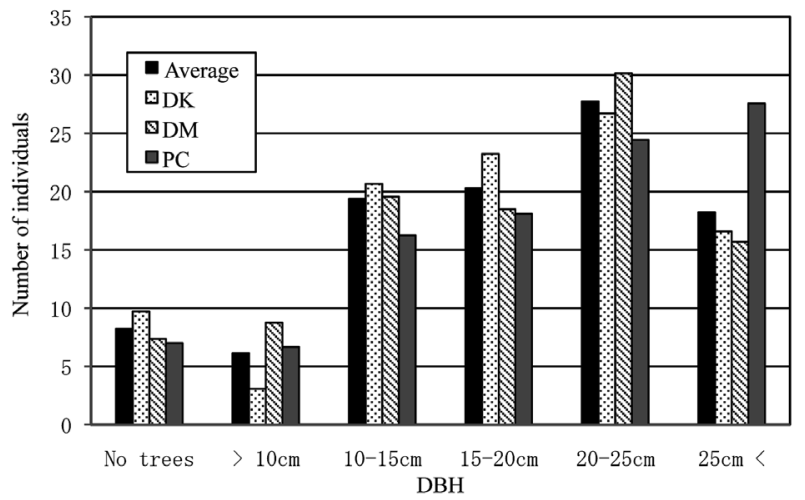

Fig. 2. Relationship between average diameter at breast height (DBH) and the number of woodpeckers appeared. DK: Dendrocopos kizuki, DM: Dendrocopos major, PC: Picus canus.

appearance of woodpeckers were influenced by the surrounding vegetation. Considering that the woodpeckers generally have their own territory and are solitary animals, they show a clear preference for the selection of nesting trees, as seen in our study. On the basis of the previous research on the choice of nesting trees by 
woodpeckers, two conflicting theories emerged. The first theory suggests that the choice of nesting tree is affected by surrounding vegetation (Swallow et al., 1986; Raphael and White, 1984; Conner et al., 1975), and the second one suggests that the nesting tree choice does not have any relation with the surrounding vegetation (Giese and Cuthbert, 2003). The results of this study concur with the first theory since woodpeckers, which had their own territories, had a clear preference of vegetation types.

\section{CONCLUSIONS}

This study determined that the Korean woodpeckers living in an urban forest had a specific preference for vegetation types when foraging for food. The appearance of woodpeckers was a little different with each woodpecker species. The vegetation types in black birch and Japanese alder forests were the most frequented by the woodpeckers. These vegetation types are the representative and dominant ones in Korean forest valleys and are formed on a humid ground. Regarding the relationships between the frequency of woodpecker appearance and tree size, the PC species appeared most frequently in trees with a large tree DBH. However, both the DM and DK species showed identical tendencies, and the number of individuals decreased where large trees were present. This behavior is probably related to the difference in biomass (relatively large and small biomasses) of woodpeckers. A large biomass woodpecker such as PC prefers large trees for roosting, foraging, or nesting compared to the other woodpeckers that have small biomasses. Urban forests are different from natural forests in terms of the environment, because urban forests are intensively used and managed. An additional research is needed to clarify the relationship between woodpecker appearance and insect habitats in urban forests.

\section{REFERENCES}

Austin, G. T. 1970 Breeding birds of desert riparian habitat in southern Nevada. Condor, 72: 431-436

Bibby, C. J., N. D. Burgess, D. A. Hill and S. H. Mustoe 2000 Bird census techniques (2Eds.). p. 302

Cho, W., S. H. Hong, J. I. Kwark and B. H. Han 2010 Analysis of the delineation accuracy of vegetation type for the information reliability of the biotope: case study of Seoul biotope map. Korean Journal of Environment and Ecology, 24: 575-581 (in Korean with English abstract)

Conner, R. N., R. G. Hooper, H. S. Crawford and H. S. Mosby 1975 Woodpecker nesting habitat in cut and uncut woodlands in Virginia. Journal of Wildlife Management, 39: 144-150

Galli, A. E., C. F. Leck and R. T. T. Forman 1976 Avian distribution patterns in forest islands of different sizes in Central New Jersey. The Auk, 93: 356-382

Giese, C. L. A. and F. J. Cuthbert 2003 Influence of surrounding vegetation on woodpecker nest tree selection in oak forests of the Upper Midwest, USA. Forest Ecology and Management, 179: $523-534$

Goodwin, R. A., J. M. Nestler, D. P. Loucks and R. S. Chapman 2001 Simulating mobile populations in aquatic ecosystems. Journal of Water Resources Planning and Management, 127: 386-393

Gunn, J. S. and J. M. Hagan 2000 Woodpecker abundance and tree use in uneven-aged managed, and unmanaged, forest in northern Maine. Forest Ecology and Management, 126: 1-12

Holmes, R. T. and J. C. Schultz 1986 Food availability for forest birds: effect of prey distribution and abundance on bird foraging. Canadian Journal of Zoology, 66: 720-728

Kwak, J. I. 2011 A study on vegetation structure characteristics and ecological succession trends of Seoul urban forest, Korea. University of Seoul. (in Korean with English abstract)

Lack, D. 1976 Island biology illustrated by the land birds of Jamaica. University of California Press, Berkeley

Landsberg, H. E. 1981 The urban climate. International Geophysics series 28. Academic Press

Linehan, J., M. Gross and J. Finn 1995 Greenway planning: developing a landscape ecological network approach. Landscape and Urban Planning, 33: 179-193

MacArthur, R. H. and J. W. MacArthur 1961 On bird species diversity. Ecology, 42: 594-598

Moss, D. 1978 Diversity of woodland song-bird populations. Journal of Animal Ecology, 47: 521-527

Raphael, M. G. and M. White 1984 Use of snags by cavity-nesting birds in the Sierra Nevada. Wildlife Monographs, 86: 1-66

Robinson, S. K. and R. T. Holmes 1982 Foraging behavior of forest birds: the relationships among search tactics, diet and habitat structure. Ecology, 63: 1918-1931

Swallow, S. K., R. H. Gutierrez and R. A. Howard 1986 Primary cavity-site selection by birds. Journal of Wildlife Management, 50: 576-583

Tilghman, N. G. 1987 Characteristics of urban woodlands affecting breeding bird diversity and abundance. Landscape and Urban Planning, 14: 481-495

Won, P. O. 1981 Illustrated flora \& fauna of Korea Vol. 25 Avifauna. Ministry of Education. (in Korean with English preface) 